\title{
Hubungan antara Motivasi Belajar dengan Hasil Belajar PJOK
}

\author{
I Made Widiana Putra ${ }^{1 *}$, I Putu Panca Adi², Made Agus Wijaya ${ }^{3}$ iD \\ ${ }^{123}$ Prodi Pendidikan Jasmani Kesehatan dan Rekreasi Jurusan Pendidikan OlahragaFakultas Olahraga dan \\ KesehatanUniversitas Pendidikan Ganesha \\ *Corresponding author: madewidana0596@gmail.com
}

\begin{abstract}
Abstrak
Berdasarkan data yang diperoleh mengenai motivasi belajar peserta didik, masih ditemukan peserta didik yang memiliki motivasi belajar yang rendah. Hal tersebut berpengaruh terhadap hasil belajar siswa. Sehingga diperlukan kiat untuk membangun motivasi siswa. Penelitian ini bertujuan untuk mengetahui hubungan antara motivasi belajar dengan hasil belajar PJOK pada materi atletik peserta didik. Jenis penelitian ini adalah expost-facto. Populasi dalam penelitian ini adalah peserta didik kelas XI Akuntansi I, Akuntasi II, dan Akuntansi III SMK N 1 Bangli yang terdiri dari kelas, jumlah sampel dalam penelitian ini yakni 99 orang peserta didik. Teknik pengambilan sampel adalah sampel jenuh. Data hasil belajar PJOK pada materi atlentik yang diambil dengan pencatatan dokumen, sedangkan data motivasi belajar dikumpulkan dengan kuesioner. Teknik analisis data yang digunakan adalah statistik deskriptif yang terdiri dari menghitung mean, median, modus, dan standar deviasi dan statistika inferensial berupa pengujian asumsi normalitas dan linearitas. Uji hipotesis menggunakan analisis korelasi korelasi product moment dengan mengkorelasikan hasil belajar PJOK pada materi antkentik sebagai variabel terikat dan motivasi belajar sebagai variabel bebas. Hasil penelitian ini menunjukkan bahwa terdapat hubungan yang signifikan antara motivasi belajar dengan hasil belajar PJOK pada peserta didik kelas XI Akuntansi SMK N 1 Bangli, yang ditunjukkan dengan hasil korelasi sebesar ${ }_{\text {hitung }}(0.97)>r_{\text {tabel }}(0.19)$. Berdasarkan analisis data dan pembahasan bahwa terdapat hubungan yang positif signifikan antara motivasi belajar dengan hasil belajar PJOK pada peserta didik kelas. Saran untuk penelitian selanjutnya dapat memahami bahwa motivasi belajar memiliki hubungan dengan hasil belajar perserta didik.
\end{abstract}

Kata Kunci : Motivasi Belajar, Hasil Belajar, PJOK

\section{Abstract}

Based on the data obtained regarding students' learning motivation, it is still found that students have low learning motivation. It affects student learning outcomes. So we need tips to build student motivation. This study aims to determine the relationship between learning motivation and PJOK learning outcomes on students' athletic materials. This type of research is ex post facto. The population in this study were students of class eleven Accounting I, Accounting II, and Accounting III at SMK N 1 Bangli, which consisted of classes. The number of samples in this study was 99 students. The sampling technique is saturated sample. PJOK learning outcomes data on athletic materials were taken by recording documents while learning questionnaires collected motivation data. The data analysis technique used is descriptive statistics consisting of calculating the mean, median, mode, and standard deviation and inferential statistics in testing the assumptions of normality and linearity. Hypothesis testing using product moment correlation analysis by correlating PJOK learning outcomes on antique material as the dependent variable and learning motivation as the independent variable. The results of this study indicate that there is a significant relationship between learning motivation and PJOK learning outcomes in eleventh-grade students of Accounting at SMK N 1 Bangli, which is indicated by the correlation result of count $(0.97)>$ rtable (0.19). Based on data analysis and discussion, there is a significant positive relationship between learning motivation and PJOK learning outcomes in class students. Suggestions for further research can understand that learning motivation has a relationship with student learning outcomes.

Keywords: Learning Motivation, Learning Outcomes, PJOK

History:
Received: 24 September 2020
Revised: 1 Oktober 2020
Accepted: 26 Oktober 2020
Published: 7 November 2020




\section{Pendahuluan}

Salah satu tantangan yang dihadapi bangsa Indonesia pada zaman modern ini adalah masalah rendahnya mutu sumber daya manusia, kemudian upaya untuk meningkatkan sumber daya manusia tersebut di antaranya adalah melalui pendidikan. Jadi pendidikan merupakan salah satu keilmuan dan lain sebagainya (Heriyansyah, 2018).

Masalah pendidikan di Indonesia, salah satunya masih berkutat pada persoalan mutu. Sampai saat ini, mutu pendidikan Indonesia masih ketinggalan jauh dibandingkan negaranegara lain di dunia, termasuk di Asia (Nilan, 2009). Rendah- nya mutu pendidikan berimplikasi pada rendahnya pula Sumber Daya Manusia (SDM). Data UNDP tahun 2009 (Kompas, 2011a) menunjuk- kan bahwa HDI Indonesia masih berada di posisi 111 dari 182 negara, jauh berada di bawah Singapura yang berada diposisi 23, Brunei 30, Malaysia 66, dan Thailand 87. Indeks pembangunan pendidikan untuk semua (education for all) menurut UNESCO dalam EFA Global Monitoring Report 2011, melaporkan bahwa Indonesia menepati urutan 67 dari 127 negara (Kompas, 2011b). Secara khusus, mutu pendidi- kan IPA juga rendah. Berdasarkan survei yang dilakukan oleh Konsorsium Internasional (2010), melaporkan bahwa dalam bidang IPA, Indonesia masuk peringkat 32 dari 36 negara (Kusmariyatni, 2012)

Teori pendidikan merupakan landasan dan pijakan awal dalam pengembangan praktik pendidikan, misalnya pengembangan kurikulum, manajemen sekolah dan proses belajarmengajar. Kurikulum dan pembelajaran memiliki keterkaitan dengan teori pendidikan atau dalam penyusunan suatu kurikulum dan rencana pembelajaran ini mengacu pada teori pendidikan (Sholichah, 2018).

Pendidikan merupakan salah satu faktor yang sangat dominan dalam perkembangan ilmu pengetahuan dan teknologi dewasa ini. Pendidikan yang baik dan bermutu akan menghasilkan manusia yang berkualitas sesuai dengan tujuan pendidikannasional. Hal ini sesuai dengan UUD RI Nomor 20 tahun 2003, pasal 3 tentang sistem pendidikan nasional yang menyatakan bahwa: "Pendidikan nasional bertujuan untuk berkembangnya potensi peserta didik agar menjadi yang beriman dan bertaqwa terhadap Tuhan Yang Maha Esa, berakhlak mulia, sehat, berilmu, cakap, kreatif, mandiri, dan menjadi warga Negara yang demokrasi dan bertanggung jawab", (Depdiknas, 2003:98).

Pendidikan jasmani (Penjas) menurut Australian Senate Enquiry into Physical and Sport Education (ASEPSE), adalah pendidikan yang mencakup semua unsur, termasuk kebugaran, keterampilan gerak, tari, rekreasi, kesehatan, permainan dan olahraga ditambah nilai yang sesuai dengan pengetahuan masing-masing (Department of Education Victoria, 1996: 3) (Qomarrullah, 2015)

Pendidikan jasmani merupakan bagian yang tidak terpisahkan dari pendidikan nasional yang bertujuan untuk pengembangkan kemampuan peserta didik melalui aktivitas jasmani (Utama Bandi, 2011). Sehingga pendidikan jasmani harus diajarkan kepada setiap peserta didik pada semua jenjang pendidikan. Perencanaan pendidikan jasmani dilakukan secara seksama untuk memenuhi perkembangan, pertumbuhan, dan kebutuhan perilaku setiap anak. Maka pendidikan jasmani bukan hanya ditujukan untuk mengembangkan kemampuan psikomotorik, akan tetapi juga mengembangkan kemampuan kognitif dan afektif peserta didik (Paramitha, 2018)

Pendidikan jasmani pada dasarnya merupakan bagian integral dari sistem pendidikan secara keseluruhan, bertujuan untuk mengembangkan aspek kesehatan, kebugaran jasmani, ketrampilan berfikir kritis, stabilitas emosional, ketrampilansosial, penalaran dan tindakan moral melalui aktivitas jasmani dan olahraga. Adang Suherman dan Agus Mahendra (2002) mengemukakan bahwa pendidikan jasmani pada dasarnya merupakan pendidikan melalui aktivitas jasmani untuk mencapai perkembangan individu secara menyeluruh. Pendidikan jasmani adalah suatu proses melalui aktivitas jasmani yang desain untuk meningkatkan 
kebugaran jasmani, mengembangkan ketrampilan motorik, pengetahuan dan perilaku hidup sehat dan aktif, sikap sportif, dan kecerdasan emosi.

Lingkungan belajar diatur secara seksama untuk meningkatkan pertumbuhan dan perkembangan seluruh ranah, yaitu jasmani, psikomotor, kognitif dan afektif, karenanya pendidikan jasmani ini harus menyebabkan perbaikan dalam pikiran (psikis) dan tubuh (fisik) yang mempengaruhi seluruh aspek kehidupan harian seseorang. Pendekatan holistik tubuh jiwa ini termasuk pula penekanan pada ketiga dominan kependidikan: psikomotor, kognitif, afektif. Pendidikan jasmani diharapkan mampu menciptakan tubuh yang baik bagi pikiran atau jiwa. Pendidikan jasmani merupakan bagian integrasi pendidikan keseluruhan yang bertujuan meningkatkan individu secara organik, muskuler, intelektual dan emosional melalui aktivitas jasmani (Wicaksono, 2019)

Berdasarkan data yang diperoleh dari salah satu guru PJOK di SMK Negeri 1 Bangli mengenai motivasi belajar peserta didik, masih ditemukan perserta didik yang memiliki motivasi belajar yang rendah. Hal ini terbukti pada saat proses pembelajaran PJOK, masih ditemukannya peserta didik bersikap malas melakukan gerakan-gerakan yang diberikan oleh guru PJOK, perasaannnya kurang gairah atau tidak bersemangat, kurang berminat atau merasa bosan, emosi yang tidak stabil, kurang pertisipasinya dalam mengikuti pelajaran sehingga cenderung merasa tidak butuh atau tidak mau mengikuti setiap aktivitas yang diajarkan. Apabila hal ini terus dibiarkan, maka akan menimbulkan pengaruh buruk terhadap aktivitas belajar peserta didik, khususnya terhadap peningkatan hasil belajar PJOK peserta didik di SMK Negeri 1 Bangli. Berdasarkan uraian di atas, peneliti tertarik untuk melakukan penelitian tentang, "Hubungan Antara Motivasi Belajar dengan Hasil Belajar PJOK pada Peserta Didik Kelas XI Akuntansi SMK Negeri 1 Bangli”.

\section{Metode}

Penelitian Pada penelitian ini rancangan yang digunakan adalah rancangan penelitian Expost Facto."Penelitian expost facto adalah penelitian yang menggunakan suatu gejala pendekatan, dimana gejala (objek) yang diteliti telah ada secara wajar tanpa perlu melakukan eksperimen untuk memunculkan variabel (objek) yang ingin diteliti" (Agung, 2014). Pada penelitian expost facto tidak adanya kontrol variabel pada penelitian ini sehingga variabel yang akan diteliti tidak sengaja dimunculkan melainkan terjadi secara alami. Jadi expost facto adalah penelitian yang terjadi secara alami tanpa adanya kontrol variabel (objek) yang akan diteliti.

Populasi adalah wilayah generalisasi yang terdiri atas objek/subjek yang mempunyai kualitas dan karakteristik tertentu yang ditetapkan oleh penelitian untuk dipelajari dan kemudian ditarik kesimpulannya" (Sugiyono, 2014: 117), seluruh objek yang dimaksud adalah orang, peristiwa atau sejenisnya yang ada dalam penelitian. Populasi dalam penelitian ini adalah seluruh peserta didik kelas XI Akuntansi SMK Negeri 1 Bangli tahun pelajaran 2020/2021 yang berjumlah99 Peserta Didik. Seluruh populasi tersebut meliputi kelas XI Akuntansi1, XI Akuntansi 2, XI Akuntansi 3. Komposisi masing-masing kelas XI Akuntansi disajikan pada tabel berikut.

Sampel merupakan kumpulan bagian (sebagian) populasi yang ditarik secara representative dari populasi" (Kanca, 2010:20). Berdasarkan hal tersebut, maka pengambilan sampel dalam penelitian ini dipilih dengan teknik sampel jenuh, teknik sampel jenuh digunakan karena penelitian ini menggunakan seluruh populasi dalam penelitian. Sehingga, dalam penelitian ini memiliki sampel yang berjumlah 99 peserta didik. Seluruh sampel tersebut meliputi peserta didik kelas XI Akuntansi SMK Negeri 1 Bangli yang terdiri dari kelas XI Akuntansi 1, XI Akuntasi 2, dan XI Akuntansi 3. 
Data yang dikumpulkan dalam penelitian ini adalah data Motivasi Belajar Peserta didik dan Hasil Belajar PJOK. Untuk memperoleh data Motivasi Belajar dan Hasil Belajar PJOK Peserta Didik menggunakan metode non-tes. Metode non tes yang dipakai adalah angket Kuesioner dengan menyebarkan ke peserta didik mengunakan aplikasi google form lewat metode virtual (daring). "Pada umumnya tujuan pengunaan angket atau kuisioner dalam proses pembelajaran terutama adalah untuk memperoleh data mengenai latar belakang peserta didik sebagai salah satu bahan dalam menganalisis tingkah laku dan proses belajar mereka" (Sudijono, 2009:84). "Angket merupakan instrumen pengumpulan data penelitian berupa sejumlah pertanyaan tertulis yang diberikan kepada responden atau subjek penelitian" (Candiasa, 2011)

Instrumen yang sudah dibuat atau telah selesai disusun harus diuji terlebih dahulu kelayakannya atau harus memiliki syarat validitas rasional. Untuk menguji kelayakan instrument kuisoner yang akan digunakan dapat dilakukan dengan cara mengujinya menggunakan uji validitas isi dan uji validitas butir soal. Selain uji validitas juga di uji reliabilitas dari instrument kuisoner tersebut. Berikut penjelasan dari masing-masing uji validitas dan uji realibilitas. Untuk menentukan apakah tes atau instrumen sudah memiliki validitas rasional atau belum, dapat dilakukan dengan penelusuran dari dua segi, yaitu dari segi isinya (content) dan dari segi susunan atau konstruksinya.Validitas isi adalah validitas yang diteliti dari segi tes itu sendiri yang digunakan sebagai pengukur"Sudijono (2009:16).

Setelah data dalam penelitian ini terkumpul, selanjutnya dilakukan analisis stastistik data. Pada penelitian ini menggunakan metode analisis data stastistik deskriptif dan stastistik inferensial.

a) Menghitung Modus (Mo)

Untuk menghitung modus digunakan rumus sebagai berikut

$$
M o=B+i\left(\frac{b_{1}}{b 1+b 2}\right)
$$

b) MenghitungMedian (Me)

(Agung, 2016)

Pada data bergolong, median dapat dihitung dengan rumus sebagai berikut.

$$
\mathrm{Me}=B+i\left(\frac{\frac{1}{n}-F}{f}\right)
$$

c) Menghitung Mean (M)

(Agung, 2016)

Untuk menghitung nilai rata-rata hitung (maen) digunakan rumus sebagai berikut:

$$
M=\frac{\sum f x}{N}
$$

(Agung, 2016)

d) MenghitungStandar Deviasi (SD)

Untuk mencari stadar deviasi (SD) dapat menggunakan rumus sebagai berikut:

$$
S D=\sqrt[i]{\frac{\Sigma f X^{2}}{n}-\left(\frac{\Sigma x t}{n}\right)^{2}}
$$

(Agung, 2016) 


\section{Hasil dan Pembahasan}

Data hasil penelitian ini membahas mengenai hasil penelitian yang sudah dilakukan. Data yang dikumpul berupa data motivasi belajar pesertadidik sebagai variabel (X) dan data hasil belajar peserta didiksebagai variabel (Y). Data motivasi belajar peserta didik diambil melalui peneybaran kuesioner dan hasil belajar siswa diambil melalui pencatatan dokumen.

Tabel 1. Deskripsi Hasil Belajar dan Motivasi Belajar Peserta Didik

\begin{tabular}{cccc}
\hline No & StastitikaDeskriptif & Hasil Belajar PJOK & MotivasiBelajar \\
\hline 1 & Mean & 76.33 & 76.45 \\
2 & Median & 75 & 75 \\
3 & Modus & 82 & 72 \\
4 & StandarDeviasi & 10.4 & 10.5 \\
\hline
\end{tabular}

Hasil rangkuman analisis statistic deskriptif data hasil belajar PJOK peserta didik Kelas XI Akuntansi SMK N 1 Bangliyakni: mean=76.33, median=75, modus=82, dan standar deviasi 10.4, sedangkan data motivasi belajar peserta didik Kelas XI Akuntansi SMKN 1 Bangli yakni: mean= 76,45, median= 75, modus $=72$, dan standar deviasi $=10.45$, perhitungan analisis data secara manual.

Tabel 2. Kriterian Penilaian Acuan Patokan

\begin{tabular}{ccc}
\hline No & Pencapaian & Kriteria \\
\hline 1. & $90-100$ & Sangat Tinggi \\
2. & $80-89$ & Tinggi \\
3. & $65-79$ & Sedang \\
4. & $40-64$ & Rendah \\
5. & $00-39$ & Sangat Rendah \\
\hline
\end{tabular}

Rata-rata hasil belajar peserta pada perhitung ananalisis data yakni 76.33 dan rata-rata motivasi belajar peserta didik kelas XI SMK N 1 Bangli yakni 76.45 yang terletak pada criteria sedang.

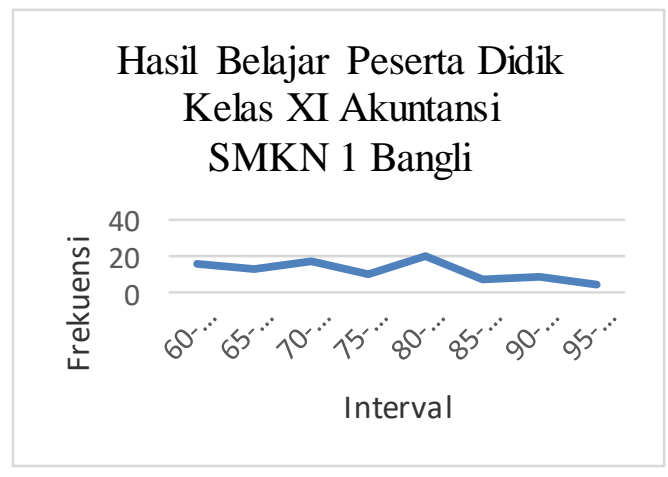

Gambar 1 . Hasil Belajar Peserta Didik Kelas XI Akuntansi SMK N 1 Bangli

Gambar diagram di atas menunjukkan hasil belajar peserta didik yang memperoleh frekuensi terbanyak terletak pada interval 80-84 dan frekuensi terendah terletak pada interval 95-99. 


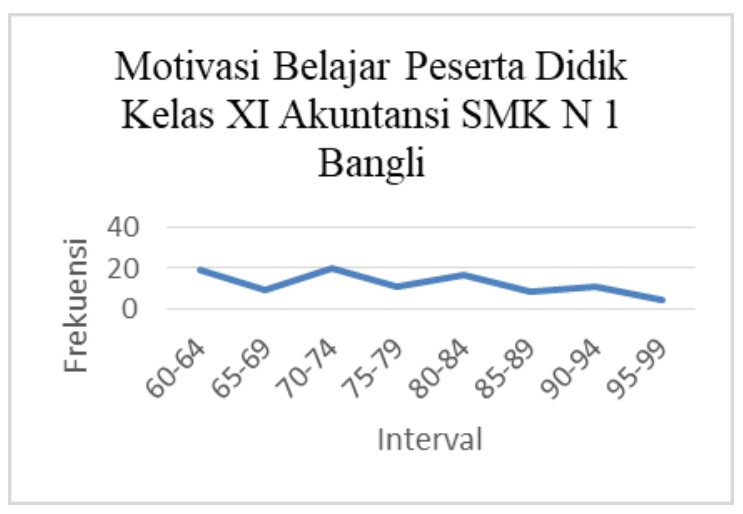

Gambar 2 . Motivasi Belajar Peserta Didik Kelas XI Akuntansi SMKN 1 Bangli

Gambar diagram di atas menunjukkan motivasi belajar peserta didik yang memperoleh frekuensi terbanyak terletak pada interval 70-74 dan frekuensi terendah terletak pada interval 95-99.

Tabel 3. Rangkuman Hasil Uji Normalitas Hasil Belajar dan MotivasiBelajar PJOK

\begin{tabular}{llllll}
\hline No & Variabel & $\begin{array}{l}\text { Hasil Pehitungan } \\
\text { Signifikansi } \\
(2-\text { tailed) }\end{array}$ & Syarat & $\begin{array}{l}\text { Nilai } \\
\text { Signifikansi }\end{array}$ & Keterangan \\
\cline { 2 - 6 } 1 & $\begin{array}{l}\text { Hasil Belajar } \\
0.12\end{array}$ & $>$ & 0.05 & Normal \\
2 & $\begin{array}{l}\text { PJOK } \\
\text { MotivasiBelajar }\end{array}$ & 0.20 & $>$ & 0.05 & Normal \\
\hline
\end{tabular}

Hasil perhitungan signifikansi menggunakan teknik Kolmogorov-Smirnov berbantuan SPSS diperoleh hasil signifikansi sebaran data hasil belajar PJOK 0.120 dan motivasi belajar 0.20 dan lebih besar dari 0.05 (sig 2-tailed > 0.05) yang artinya data berdistribusi normal dan hasil pengujian.

Tabel 4. Rangkuman Uji Linearitas Hasil Belajar dan MotivasiBelajar

\begin{tabular}{ccccc}
\hline Variabel & Sig. Linearity & $\begin{array}{c}\text { Nilai Sig. } \\
\text { Linearity }\end{array}$ & $\begin{array}{c}\text { Sig. Deviation } \\
\text { From Linearity }\end{array}$ & $\begin{array}{l}\text { Nilai } \\
\text { Deviation From } \\
\text { Linearity }\end{array}$ \\
\hline $\begin{array}{c}\text { Hasil Belajar PJOK (Y) } \\
\text { dan MotivasiBelajar } \\
\text { PJOK }\end{array}$ & 0.00 & 0.00 & 0.79 & 0.05 \\
\hline
\end{tabular}

Kriteria pengujian uji linieritas yakni apabila diperoleh nilai signifikansi linearity< 0.05 dan nilai signifikansi deviation from linearity $>0.05$, maka hubungan antar variabel linier, adapun hasil rangkuman uji linearitas yakni nilai signifikansi linearity $0.00<0.05$ sehingga motivasi belajar dan hasil belajar PJOK peserta didik kelas XI Akuntansi SMK N 1 Bangli memiliki hubungan yang linear dan nilai signifikansi deviation from nilearity $0.79>$ 0,05 yang artinya motivasi belajar dan hasil belajar PJOK peserta didik kelas XI SMK N 1 Bangli memiliki hubungan yang bearti, hasil uji linearitas. 
Tabel 5. Rangkuman Hasil Uji Hipotesis

\begin{tabular}{lllll}
\hline \multicolumn{1}{c}{ Variabel } & $\mathbf{r}_{\text {hitung }}$ & $\mathbf{r}_{\text {tabel }}$ & Syarat & Keterangan \\
\hline $\begin{array}{l}\text { Motivasi Belajar dan Hasil } \\
\text { Belajar PJOK }\end{array}$ & 0.97 & 0.16 & $>$ & Signifikan \\
\hline
\end{tabular}

Tabel di atas menunjukkan nilai $r_{\text {hitung }}$ sebesar 0.97 dan $r_{\text {tabel }} 0.16$ yang artinya $r_{\text {hitung }}>r_{\text {tabel }}$ sehingga hasil pengujian hipotesis menunjukan terdapat hubungan antara motivasi belajar terhadap hasil belajar PJOK peserta didik kelas XI Akuntansi SMK N 1 Bangli dan hasil uji hipotesis. Penelitian ini didukung dengan beberapa penelitian yang relevan yaitu, penelitian yang dilakukan oleh (Abidin, Zainal, 2018), (Yuliany, 2018) yang memperoleh hasil bahwa terdapat hubungan yang signifikan antara motivasi belajar dengan hasil belajar. Motivasi belajar berhubungan positif dengan prestasi belajar siswa. Hal in menunjukkan bahwa bila motivasi belajar meningkat berarti ada kecenderungan bahwa hasil belajar juga dapat meningkat, demikian pula dengan sebaliknya (Muhajis, 2018).

Implikasi Penelitian

Motivasi belajar dalam kegiatan pembelajaran PJOK sangat diperlukan oleh oleh peserta didik untuk dapat mendorong peserta didik melakukan aktivitas-aktivitas yang terdapat dalam kegiatan belajar pembelajaran baik itu aspek afektif, kognitif, maupun psikomotor. Motivasi belajar dalam kegiatan pembelajaran PJOK sangat diperlukan agar kegiatan peserta didik dapat mengikuti kegiatan pembelajaran yang sesuai dengan dan tujuan pembelajaran dapat tercapai hasil belajar yang sesuai dengan harapan. Motivasi belajar dalam kegiatan pembelajaran PJOK tidak hanya dapat dibangkitkan oleh diri peserta didik, namun peran seorang guru untuk menumbuhkan motivasi belajar peserta didik misalnya dengan menjelaskan maksud dan tujuan tugas yang akan diberikan, memberikan cara orientasi sukses, modifikasi cabang olahraga, motivasi dalam diri anak, pengajaran dengan menawarkan tugas, dan variasi antar tugas ajar. Untuk itu, tugas gerak disesuaikan dengan kemampuan siswa dan kriteria berhasil juga disesuaikan dengan tingkat perkembangan peserta didik.

\section{Simpulan}

Simpulan dalam penelitian ini adalah terdapat hubungan yang positif signifikan antara motivasi belajar dengan hasil belajar PJOK peserta didik kelas XI Akuntansi SMKN 1 Bangli. Hal ini ditunjukkan oleh hasil pengujian hipotesis dengan nilai $r_{\text {hitung }}$ sebesar 0.97 dan $r_{\text {tabel }} 0.16$ yang artinya $r_{\text {hitung }}>r_{\text {tabel }}$ sehingga hasil pengujian hipotesis menunjukan terdapat hubungan antara motivasi belajar terhadap hasil belajar PJOK peserta didik kelas XI Akuntansi SMK N 1 Bangli.

Penelitian ini dapat memberikan saran kepada peserta didik agar meningkatkan motivasi belajar khususnya pada pelajaran PJOK sehingga memperoleh hasil belajar yang maksimal. Penelitian ini disarankan dapat meningkatkan kerja sama yang baik antara guru dan orang tua untuk meningkatkan motivasi belajar peserta didik dalam mengikuti kegiatan pembelajaran PJOK. Sekolah disarankan dapat meningkatkan motivasi peserta didik dalam kegiatan pembelajaran sehingga peserta didik memperoleh hasil belajar PJOK dengan maksimal, sehingga dapat bersaing dalam kompetensi antar sekolah baik untuk terjun ke masyarakat maupun untuk kepentingan melajutkan studi ke jenjang yang lebih tinggi. Serta bagi peneliti selanjutnya memberikan wawasan dan pengetahuan tentang penelitian mengenai motivasi belajar terhadap hasil belajar pendidikan jasmani sehingga peneliti memperoleh pengalaman dalam melaksanakan kegiatan penalitian ilmiah dan dapat mengembangkan penelitian ini dengan mengaitkan metode, strategi, maupun model pembelajaranlainnya. 


\section{Daftar Pustaka}

Abidin, Zainal, S. I. (2018). Hubungan Motivasi Belajar Dengan Hasil Belajar Pada Siswa Kelas V SD Negeri Gugus IV Kecamatan Banuhampu Kabupaten Agam. Jurnal Inovasi Pendidikan Dan Pembelajaran Sekolah Dasar, 2(2). Retrieved from http://ejournal.unp.ac.id/index.php/jippsd

Agung, A. A. G. (2014). Metodologi Penelitian Pendidikan. Yogyakarta: Aditya Medika Publishing.

Agung, A. A. G. (2016). Statistika Dasar Untuk Pendidikan. Yogyakarta: Deepublish.

Candiasa, I. M. (2011). Statistik Multivariat Disertai Aplikasi. Universitas Pendidikan Ganesha.

Heriyansyah. (2018). Guru Adalah Manajer Sesungguhnya Di Sekolah. Jurnal Manajemen Pendidikan Islam, I(1).

Kusmariyatni, N. (2012). Model Brain Based Learning Dan Hasil Belajar Ipa Siswa Sekolah Dasar. Jurnal Pendidikan Dan Pengajaran, 46(2).

Muhajis, D. \&. (2018). Analisis Hubungan Antara Motivasi Belajar Dengan Hasil Belajar Siswa Pada Sekolah Dasar Negeri 3 Allakuang Kecamatan Maritengngae Kabupaten Sidenreng Rappang. Jurnal Idaarah, II(2), 216-228.

Paramitha, S. T. (2018). Revitalisasi Pendidikan Jasmani untuk Anak Usia Dini melalui Penerapan Model Bermain Edukatif Berbasis Alam. JPJO, 3(1), 41-51.

Qomarrullah, R. (2015). Model Aktivitas Belajar Gerak Berbasis Permainan Sebagai Materi Ajar Pendidikan Jasmani. Journal of Physical Education, Health and Sport JPEHS, 2(2).

Sholichah, A. S. (2018). Teori-Teori Pendidikan Dalam Al-Qur'an. Jurnal Pendidikan Islam, $7(1)$.

Wicaksono, G. H. (2019). Kreativitas Guru Penjas Terhadap Proses Pembelajaran Penjas Di Sekolah Menengah Pertama Negeri Sekecamatan Kebumen Kabupaten Kebumen 2018. Jurnal Pendidikan Kesehatan Rekreasi, 5(2), 95-100.

Yuliany, N. (2018). Hubungan Antara Motivasi Belajar Dan Hasil Belajar Siswa Sdn Emmy Saelan Makassar. Jurnal Pendidikan Dasar Islam, 5(2). https://doi.org/DOI: https://doi.org/10.24252/auladuna.v5i2a1.2018 